\title{
The evolution of industrial democracy in a small- island economy, Mauritius
}

\author{
Nirmal Kumar Betchoo \\ Université des Mascareignes, Arianne St, Beau Bassin-Rose Hill, Mauritius \\ E-mail address: betchoonirmal@yahoo.com
}

\begin{abstract}
This research work concerns an evaluation of the Employment Relations Act 2008, ERA 2008, from its inception in 2008 up to the present date. Considered as a major revolution in industrial relations, the legislation has met with mitigated results. Firstly, trade unions have contested the legislation in terms of loopholes and inadequacies concerning employee protection. Secondly, the public including people at work are not fully knowledgeable of the legislation because of its complexities and numerous issues that are addressed but not looked into. The assessment of the ERA is seen from the perspectives of employee relations whereby it addresses better the pluralistic perspective since Mauritius, a small-island economy in the Indian Ocean, has maintained its cultural identity of democracy and alongside industrial democracy. The research emphasises that through amendments to the legislation, it is seen that employee relations must sound and dynamic to maintain the concept of industrial democracy and see that employees are better off with the ERA 2008 since it replaced the former Industrial Relations Act (1973).
\end{abstract}

Keywords: employee relations; employment legislation; industrial democracy Mauritius

\section{INTRODUCTION}

\section{The Industrial Relations Act 1973}

Employment legislation has been the framework of effective industrial relations in Mauritius since the 1930s. It has prevailed in an environment dominated by a feudal system with more of employer influence in the sugar sector, the prevailing dominant sector up to the seventies. Since the 1970s, employee relations grew turbulent in a climate characterised by strike action in several sectors of the Mauritian economy that paralysed the docks, transport, sugar sector and even attaining white-collar sectors like education in private schools. Consequently, the Industrial Relations Act was promulgated in 1973 to counter such actions but also to see that violence upsurge and unrest could be curbed to ensure peaceful stability in Mauritius.

Trade unions, during that time viewed the legislation mainly as a deterrent to industrial action since it was linked with the perception of repression, uplifting of the individual's 
liberty and the threat of imprisonment for any form of deviation from such legislation. If the perception of opposition parties during the 1970s was at odd ends with that of the government, it implied that IRA could be an attempt to counter ongoing pressure from trade unions which could benefit from such a difficult industrial climate. Certain issues within the IRA could relate the legislation to a ,loi baillon ${ }^{\text {eel }}$, the rule-of-the-thumb in the years following the state of urgency. When the regime was discharged from power in 1982, the population wanted to feel assured that new changes to the IRA could offer more opportunities for individual and civil liberties.

The IRA remained practically the same when the new government stepped to power while the Public Order Act (POA), a complementary legislation was reviewed and renamed the Public Gathering Act (PGA) by 1983. Several issues within both legislations were frequently discussed but few remained solved. For example, the forty-hour week looks more like a compromise than a solved problem while inequalities concerning sex differences and jobs have been approached with some nuance without correcting anomalies that still persist.

From this point, it would be good to ponder whether new amendments to the IRA will offer wider avenues for industrial democracy to employees or whether there would be merely cosmetic changes. Trade unions will surely not appreciate the style, „Plus ça change ${ }^{\mathrm{e} 2}$ or associate the new developments with an existing cliché like the legislation is good in the form but not in essence.

\section{DISCUSSION}

\section{The need for modern legislation}

The critical issue behind expecting a more subtle form of legislation is that trade unions and employees are willing to have wider industrial democracy at the place of work. Industrial democracy is not the most ideal form or employee participation but it is one of those concepts that can help Mauritius gain more credibility as a free state that offers room for human development. It still looks strange that Mauritius has maintained a consistent position at the level of human development in the sub-Saharan region according to a UN rating yet its workplace legislation has not made important leaps forward.

Ideally Mauritius should expect more flexible and improved industrial relations compared with the actual legislation that offers limited possibilities for employee freedom. For example, the right to strike action is prohibited as government views this to be countereffective to the countryes advancement. The fact that the country is an export-oriented economy makes it a reasonable argument to withhold industrial strike. Most governments seem to be careful on this issue as they may not want to see the country in a chaotic situation where law and order are threatened [1].

If strike action is still feared, IRA must make more provision for go-slows. In the actual context, employees can risk the threat of being laid off for some valid reason and also subject to legal action following a go-slow. Apparently, go-slows should not be treated to a similar level as strikes. Industrial democracy pictures go-slows as measures to create disobedience in a civilly acceptable way. Civil disobedience undertaken in a peaceful way with strong justification for such an action should be accepted as normal and reasonable.

\footnotetext{
${ }^{1}$ Baîllon: a French term relating to blocking employee freedom of speech

${ }^{2}$ The more it changes, the more it remains the same (adage)
} 


\section{Dynamics of the modern western workforce}

Apart from the United Kingdom, most nations in the European Union tolerate strikes and go-slows. If was not unusual to hear in the past years the chain of strike action that affected France and spread deeper into Europe. The first assessment was that these countries would have economics that would be shaken by strike action and that annual growth would be very poor. In fact, such condition rarely persists for a long time. Rather, occasional industry turmoil helps the western economies to readjust to changes.

If this perspective were translated to an open marked economy like Mauritius, it would be fair to say that industrial democracy would become more evident in the country. The argument here is not to appraise industrial strike or go-slow as a much-deserved right but to state that these factors comprise the dynamics of a developing economy. Haven 't we heard of stagflation that occurs among economies that are too stagnant and are chronically affected by inflation? The main cause is that such economies fail to recognise the importance of workforce dynamics and the essence of industrial democracy.

\section{Industrial democracy in practice}

Apart from more flexibility expected from go-slows and strike action, industrial democracy must give more opportunity for employee participation in negotiation. The actual position of the private sector favours a more paternalistic management style than encouraging employee democracy. Recent moves of the private sector were aimed at replacing the actual tripartite with a new form of controlled collective bargaining. However, collective bargaining as translated to the Mauritian reality looks to be more distant and weaker as a negotiation approach than tripartite during compensation and salary revisions. Government may need to consolidate the right for employee participation in tripartites and allow trade unions negotiate freely without overemphasising the threat of job loss which is caused by an adverse economic environment [2].

A lot has been said on the participation of women at the workplace. If gender representation is fair at executive positions in the government, little can be said of progress achieved in the private sector. At this stage, there are reasons to argue in favour of more female participation at upper levels in private organisations. In order to see this as a possibility, trade unions should firstly provide chances for female representation in collective bargaining where women can also voice their opinion on key issues affecting them. Actually, most of the debate concerning female emancipation is centred at Ministryes level but too sparsely among trade unions.

The forty-hour week should be more thoroughly debated as it constitutes the flagship of industrial democracy. The reduction of working hours and a better equilibrium of a three-tier day offer more motivation to the workforce. Japan is now lowering to less than forty hours believing that Japanese need to work and rest, and not be called workaholics. In France, the ,semaine de trente-cinq heures ${ }^{3 e e}$ helps saving jobs in industry. In Mauritius, the five-day week in several sectors has helped reducing absenteeism on Mondays considered as ,lundi cordonnier $^{\text {et }}$ in a recent past. It is important to rethink of the forty-four week in several sectors, more importantly, in occupations requiring enduring physical effort.

The arguments discussed in this article should not be considered as prescriptions to better industrial harmony. They are just an evaluation of the variety of issues that a revamped

\footnotetext{
${ }^{3}$ Semaine de trente-cinq heures: French locution for 35 hour-week.

${ }^{4}$ Local Mauritian term for marked absenteeism at work on Mondays.
} 
IRA, enforceable as from next year, should essentially cover. In a world characterised by the need for more individual freedom, the consolidation of civil liberties and the creation of wealth, more equitably spread so as to reduce the poverty gap, it would be rewarding to see how far such debatable and thought provoking issues so fundamental to workers need to contained within the IRA. There is the expectation that the Mauritian workforce does not want to be deceived but considers such a long awaited change as an opportunity to align Mauritius with Industrial democracy and progress so endearing to a limited number of successful western economies.

\section{Implementing the Employment Relations Act 2008}

The Government of Mauritius implemented a new Employment Relations legislation to repeal the former Industrial Relations Act (1973), which is now obsolete in a milieu where the work pattern, technology, pace of work, and so forth are changing more rapidly than ever before. Additionally, there are contemporary issues like globalisation and international competition impacting employee relations. The increasing integration of national economies into the global market is demanding stronger integration of national trade union agendas [3]. With these changes, the role and orientation of trade unions in Mauritius has to evolve as well.

Trade unions presently act within a workplace where the dynamics have changed. For example, it has already been seen that trade unions can hardly mobilise employees around them to create the powerful workforce, which made management respond to their demands in the past. Pedersini considers membership as a key resource for trade unions while being a crucial component of a union ${ }^{\text {ee }}$ organisational strength and a fundamental element for legitimacy and recognition [4]. This trend, at the international level, is now clearly depicted in Mauritius whereby unionsee influence has become marginal over the years following its industrial development. Trade unions come forward with the same agenda of improved pay and improved work conditions, while they are not really in a position to say that their orientation has changed. Unions still bear in mind that the emotional intelligence that they use in collective bargaining will bring them an opportunity to succeed in their task [5].

Trade unions have evolved under a paternalistic work structure, both in public and private sector organisations. Trade Unions in Africa are weak organisations with many internal problems [6,7]. Trapped between an ongoing deregulation of the African economies on the one hand and the consequences of neo-liberal globalisation on the other, they are quite often seen to be a relic of the past [7]. They have had enough arguments to bargain with employers in the past like wage rises, job insecurity and worker exploitation.

Today's work pattern is different since employers base their strategies not on their personal aims or orientations but also, to a large extent, on global factors which influence the nature of business. Employers are getting wearier of changes and seem to have put trade unions in a weak position whereby their bargaining power has drastically been reduced [8]. With globalisation and liberalisation, the Mauritian trade union movement is faced with new challenges.

Trade unions can no longer confine themselves to such traditional issues as better conditions of work, but must deal with issues such as globalisation, sustainable industrialisation and the linkage between trade and environment, and related WTO issues [9]. This explains their need to broaden their spectrum and seek new concepts that are successfully applied elsewhere. 


\section{An overview of theories on Employee Relations}

There are three major perspectives that contrast in their approach to the nature of workplace relations. The three views are: the Unitary, Pluralist and Marxist perspectives. Each offers a particular perception of workplace relations and will therefore interpret such events as workplace conflict, the role of trade unions and job regulation in a different way.

The Unitary perspective regards the organisation as an integrated group of people with one loyalty structure and unified by a common purpose. It means that there are no barriers between different groups and departments which could lead to poor communication and animosity, which would go against the notion of common values and common goals as that would not be advantageous to the common goal, of the success of the organisation. It is characterised by an integrated group of people, centralised authority and loyalty structure and a group of people have common values and interest. Furthermore, unitary perspective accepts that organisations only exist in perfect harmony and conflicts are not necessary [10].

However, the unitary approach however cannot easily accommodate non-conforming individuals. Unitary managers do not accept differing viewpoints, criticism of organisational norms and universal directions and people who are unwilling to be absorbed into the whole. Moreover, although trade unions try to balance the unfair empowerment, the organisations still insist to wipe off the presence of trade unions, because trade unions are threats for organisations to build up employees ${ }^{\text {ee }}$ loyalty. The unitary perspective seems to be more suitable for nineteenth-century, while the pluralist perspective seems to be appropriate for contemporary society [11]. The organisations are characterised by a widespread distribution of authority, ownership separated and political and industrial conflict separated.

The Marxist perspective has been a tendency which prefers to focus on the politics of a society, according to Marx ${ }^{\text {ee }}$ s theory, while both unitary perspective and pluralist perspective pay attention on industrial relations inside organisations. Marxist perspective criticises the capitalist society and its system of production, distribution and exchange [12]. The critical analysis of the Marxist perspective includes social, political and economic structure. This perspective has broader range than the other two perspectives since it not only analyse the relations in organisations, but also in social, political and economic terms. There are some assumptions made by Marxist perspective. Firstly, social class conflict promotes the society development. Without the social class conflict, society may stagnate. Additionally, the distribution of economic power is not equal to the different class, so it causes the class conflict. Thirdly, the inequality is between the people who own the capital or materials and others who supply and sell their labour. Furthermore, the society ${ }^{\text {ee }}$ social and political regulations are based on the economic inequality. And finally, the social and political conflict is an expression of underlying economic conflict [13]. The unequal division between who own the capital in the organisations and who sell their labour causes conflict, and Marxism believes conflict is constant and inherent within the employee relationship. In this case, within capitalism society, this kind of conflict is unavoidable and inherent, and also the political and social conflict and would result in revolution and the ascendency of socialism over capitalism. The employees ${ }^{\text {ee }}$ salaries would be minimised to a subsistence level. Ultimately Marxists believe the only way resolve the conflict would be the abolition of capitalism. Trade unions, as a product of the conflict, may focus on the expression and protection of proletariat class. As a part of political process, trade union may gain the basic changes in the nature of economic and social systems.

The Pluralist perspective regards organisation as combination of composed of a variety of sectional groups with divergent interests over whom the government tries to maintain some kind of dynamic equilibrium [14]. The organisation is seen as multi-structured in terms 
of groups, leadership, authority and loyalty. The two main groups in Pluralist perspective are workers and managers. Because the different position these two groups stand, the purposes for working are different. In this case, conflicts are inevitable and legitimate, which due to the disagreement such as pay, working conditions, bonuses and working hours [15]. Pluralists believe that the interests of their employees compete with the organisations interest. For instance, workers want higher salaries or better working conditions, but organisations need to reduce the cost in order to maximise the profit. Pluralist perspective managers recognise the conflict; hence they try to solve the conflict by appropriate methods, for example, negotiation and bargaining and sharing decision-making information.

In Mauritius, the appropriate perspective should be pluralist perspective. All employees and employers have their own interests about work. Due to this reason, employees may not have common goal with employers. So conflict will appear. Unitary perspective regards conflict as irrational activities. That means unitary managers do not accept employees who has different working goals. Unitary perspective can only exist in ideal conditions [16]. The pluralist ideology reflects organisational and social changes happening in the mid-twentieth century to late twentieth century and extending into twenty-first century. This means that unitary perspective is less important and used more rarely in recent organisations. According to the Involvement and Participation Association [17], Pluralists believe that such differing interest can be managed to avoid open conflict and can be channelled to produce more positive outcomes.

Moreover, in the 1970s and 1980s, the employee relations se climate in the Mauritius gave considerable attention to their pluralistic, union-management policies, since pluralist perspective is a pragmatic, effective alternative to the Unitarist perspective. According to the Pluralist perspective, authority is controlled by the mass of population, rather than by a small leader group. Mauritius is a traditional country that focuses on the human rights. In this situation, the reason why the pluralist perspective is appropriate for Mauritius could be argued as follows [18]. The pluralist perspective illustrates that if a majority of people do not like what their representatives or leaders are doing, they may make the representatives or leaders resignation through voting at the next election. Blyton and Turnbull state that the Pluralist perspective insists that employees could join in interest groups such as pressure groups and trade unions in order to protect this kind of authority.

\section{Creating a new work environment under the ERA}

Broadly, the new Employment Relations Act does not represent a fundamental change in approach to industrial relations but attempts in some ways to look into matters that were not well covered in the past and where corrective action was not initiated. Accordingly, it has opened the doors for the possibility to negotiate a well-defined group of elements forming the essence of the contract of employment [19]. It does not therefore represent a dramatic change from the Industrial Relations Act 1973 (IRA) but serves as an opportunity to review the former legislation with the new workplace environment.

The new Employment Relations Act comes in as a salutary initiative since it considers the human dimension of the work environment. Bryson views that if management-employee relations are a workplace attribute, one would expect a high degree of agreement about the state of those relations in a particular workplace [20].

Rather than assuming that rules should be promulgated in a mechanistic and bureaucratic environment, the ERA seeks opportunities to transform the human resource management philosophy in Mauritius. The ERA Report 2008 suggests that the new Act is basically transitory in nature with improvements brought in several areas. The credit goes to 
recognising trade unionism, consolidating worker rights while extending opportunities for better productivity through some reengineering of sick and casual leaves [21].

\section{The role of trade unions}

Trade unions will have their part to play although they must clearly accept that an employee-focused industrial relations strategy is far better than a profit-based or productivitybased one. Workersee perceptions of management-employee relations depend on practices and structures underpinning the relationship between management and employees (both collectively and individually) as well as individuals ${ }^{\text {ee }}$ own work experiences [22].

The new legislation is not free from shortcomings and criticism but the replacement of the former IRA remains a positive effort to give a face-lift to industrial relations in a contemporary context. So far, the essence of the change remains a good initiative although some refinement through representation and debate deserve to be encouraged in this democratic workplace environment of that Mauritius boasts within sub-Saharan Africa. The new Employment Relations Act does not come forward as a paradigm shift in industrial relations. The Act therefore marks the beginning of a new era in approach to the principles underpinning the employment laws of Mauritius [23]. It rather considers changes in a subtle way while bringing in some modifications, which fit in the contemporary context of industrial relations.

\section{CONCLUSIONS}

Employee relations have evolved with time and the importance of the ERA 2008 is more felt in todayes context when employment attains $8 \%$ of the working population in Mauritius. The legislation came forward as a major change in employee relations since its initial drafting in 2004 [24]. It is a much more improved version of the Industrial Relations Act with focus on creating trade unions within organisations and aiming at widening democracy. Employers are against the creation of trade unions in the private sector while employees in private firms find it difficult not to be represented by trade unions in their pledges for better working conditions. Industrial relations in countries, sub-regions and regions, have been influenced by a variety of circumstances and actors such as political philosophies, economic imperatives, and the role of the State in determining the direction of economic and social development, the influence of unions and the business community, as well as the legacies of colonial governments [25,26].

Consequently, the International Labour Organisation (ILO) accepts the conventions that Mauritius adopted in several fronts whereby industrial democracy was practised and even mentioned how this positively influenced human development index in sub-Saharan Africa. In democracies, trade unions will apparently voice what they feel and in circumstances where legislation is already a handicap for them since many work statutes are implemented by the government to protect employee rights, unions will view the legislation as negative. However, after six years since it has been implemented, it has to be seen how the ERA posits itself as a useful yardstick in new work conditions affected by speculation, external markets, deregulation and a more competitive global economic climate upon which Mauritius is dependent and counts really much for its survival. 


\section{References}

[1] Betchoo N. K. (2006). Labour Day, beyond the symbol, Leexpress.

[2] Betchoo N. K. (2009). Evolutionary Concepts in HRM, Pan Art Edition, National Library, Mauritius.

[3] Schmidt V. (2007). Trade unions and globalization: trends, challenges and responses, International Labour Organisation.

[4] Pedersini J. (2010). Trade union strategies to recruit new groups of workers, University of Milan, Italy.

[5] Dempsey M., Brewster C. (2009). "On leaving the nunnery: management in trade unions", Employee Relations, Vol. 31.

[6] Schillinger R. (2005). Trade Unions in Africa, Weak but feared, Occasional paper, International Development Cooperation.

[7] Government of Mauritius (2004). White Paper on the Employment Relations Act 2008. Ministry of Labour and Industrial Relations, Mauritius.

[8] Kamoche K. (2004.) Managing Human resources in Africa, Psychological Press.

[9] Bhowon V., Boodhoo N., Chellapermal A. (2004). Mauritius: Policy making in Africa in Soludo C (2004) The Politics of trade unions and industrial policy in Africa (2004), Africa World Press.

[10] Salamon, G. (1992) Human Resource Management, a strategic introduction, Blackwell. Government of Mauritius (2010). Employment Relations Act 2008.www.gov.mu

[11] Rose M. (2004). Industrial Behaviour. Harmondsworth: Penguin.

[12] Blyton P., Turnbull P. (2004). The dynamics of employee relations, Basingstoke: Palgrave Macmillan.

[13] Ibid 11.

[14] Ibid 11.

[15] Ibid 12.

[16] Ibid 11.

[17] Involvement and Participation Association (2002). „Definitions of partnership September 25 2002, http://www.partnership-at-work.com/pardefs

[18] Ibid 12

[19] Appleby (2009). Guide to Employment Law in Mauritius, Applebyglobal.com.

[20] Bryson A. (2011). Workplace Employment Relations Survey 1980-2011, National Institute of Economic and Social Research.

[21] Week-End (2008-2010). Articles related to Employment Relations Act, Le Mauricien. Ltd.

[22] Katz H., Kochan T., Weber M. R., Academy of Management Journal 28(3)(1985) 509-526.

[23] Ibid 19. 
[24] White Paper on a New Legal Framework for Industrial Relations in Mauritius (2004). Ministry of Labour, Industrial Relations and Employment, Mauritius.

[25] Silva S. (1997). The Changing Focus of Industrial Relations and Human Resource Management Bureau For Employers' Activities, International Labour Office, Geneva, April, 1997.

[26] Nirmal Kumar Betchoo, International Letters of Social and Humanistic Sciences 16(1) (2014) 39-48. 